\title{
Bank Capital Adequacy Requirements And Risk-Taking Behavior In Tunisia: A Simultaneous Equations Framework
}

Faten Ben Bouheni, Ph.D., Professor at ISC Paris Business School \& Researcher at LITEM Research Laboratory, France Houssem Rachdi, Ph.D., University Of Jendouba \& University Of Tunis El Manar, Tunisia

\begin{abstract}
We extend exiting literature on the efficiency of capital adequacy requirements in reducing risktaking behaviour of Tunisian commercial banks using a new risk measure: the weighted-assets to total assets. Thus, using a simultaneous equations framework, we reach four main results. First, interaction between capitalization and risk level is negative, which means that an increase in capital is followed by a decrease in banking risk-taking. Second, Tunisian banks dispose of a weak institutional and regulatory level. Third, largest banks are the best managers of their risk, since they have more experience in managing risk levels through diversification. Finally, we found a negative relationship between size and bank capitalization, indicating that more bank is large, more its risk level is low.
\end{abstract}

Keywords: Tunisia; Risk-Taking; Bank Capital Adequacy Requirements; Simultaneous Equations

\section{INTRODUCTION}

$n$ response to the recent global financial crisis, regulators have increased their focus on capital adequacy
of banking institutions in order to enhance stability of the financial market. Therefore, how do bank
capital adequacy requirements affect risk? The Basel Committee on Banking Supervision (BCBS) was set forth to update the guidelines for capital and banking regulations. Basel III proposes many new capital, leverage, and liquidity standards to strengthen regulation, supervision, and risk management in the banking industry. Capital standards and new capital buffers will require banks to hold more capital and a higher quality of capital than what was required by the current Basel II rules (Lee and Hsieh, 2013).

The recent credit crisis revealed the need to further understand bank risk determinants in an environment of lower bank capital (Festic et al., 2011). For instance, in 2008 the Federal Reserve Board of the U.S. proposed a rule for public comment that would institute certain less-complex approaches for calculating risk-based capital requirements. The proposal, known as the standardized framework, would be available for banks (Lee and Hsieh, 2013). However, the European Union has already implemented the Basel II accord via the EU Capital Requirements Directives, and many European banks have already reported their capital adequacy ratios according to the new system. All credit institutions in the EU adopted Basel II at the beginning of 2008.

Although banking regulation and supervision are being rewritten and restructured in response to the global financial crisis, their implementation requires complex steps depending on each country's national policies which could have different effects on bank risk-taking depending on the financial and institutional environment in which the banks operate (Ben Bouheni, 2013). It is thus not surprising that the relationship between bank regulation and risk has recently become a hot topic. However, empirical studies on this topic are inconclusive and mixed. For example, Barth et al. (2008) find that some Asian countries, like the Philippines, Singapore, and Indonesia, are strengthening capital requirements, while some others are easing their capital requirements in the aftermath of their crises, like South Korea and Japan. This differs from Argentina, which made the same move, but in advance of the 
crisis. At the same time, South Korea, Malaysia, Singapore, and Thailand provided supervisors with more explicit power.

The remainder of this paper is organized as follows: The second section will review the existing theoretical and empirical literature on capital adequacy-risk nexus. The third section describes the data, the selected econometric methodology and the main findings. Section 4 provides conclusions.

\section{LITERATURE REVIEW}

Previous studies on the relationship between capital and risk reached mixed results. Some studies found a positive relationship between capital and risk, suggesting that regulators encourage banks to increase their capital commensurably with the amount of risk taken (Pettway, 1976; Shrieves and Dahl, 1992; Berger, 1995; DemirgucKunt and Huizinga, 2000; Iannotta et al., 2007; etc.). Nevertheless, opposite results are found in some studies. A negative relationship between capital and risk may refer to the 'moral hazard hypothesis' whereby banks have incentives to exploit existing flat deposit insurance schemes (Demirguc-Kunt and Kane, 2002). For instance, Jahankhani and Lynge (1980), Brewer and Lee (1986), Karels et al. (1989), Jacques and Nigro (1997), and Agusman et al. (2008) showed that equity-to-total assets negatively relates to risk. As also indicated by Kahane (1977), Koehn and Santomero (1980), and Kim and Santomero (1988), banks could respond to regulatory actions, forcing them to increase their capital by increasing asset risk (Altunbas et al., 2007). However, the puzzle between capital and risk, as suggested by Hughes and Moon (1995), Hughes and Mester (1998), and Altunbas et al. (2007), is that capital and risk are likely to be influenced by level of profitability of the banking sector.

Traditional approaches to bank regulation emphasize the positive features of capital adequacy requirements. Capital serves as a buffer against losses and failure. Furthermore, with limited liability, the proclivity for banks to engage in higher risk activities is curtailed by greater amounts of capital at risk (Ben Bouheni, 2014). Capital adequacy requirements, especially with deposit insurance, play a crucial role in aligning incentives of bank owners with depositors and other creditors (Berger et al., 1995; Keeley and Furlong, 1990). In his report, Murphy (2013), based on the decision of the European Union in 2013 that limited the ratio of variable remuneration to fixed remuneration, showed that the pending EU regulations restrictions will: (1) increase rather than decrease incentives for excessive risk-taking; (2) result in significant increase in fixed remuneration; (3) reduce incentives to create value; (4) reduce the competitiveness of the EU banking sector; and (5) result in a general degradation of the quality of EU investment bankers, thereby decreasing access to capital and increasing capital cost in the European Union.

However, Rime (2001) examines the relationship between risk and capital in commercial banks during the period 1989-1995, using a simultaneous equations model to analyze adjustments in capital and risk in Swiss banks. He found that regulatory pressure induces banks to increase their capital, but does not affect risk level. He concluded that this result indicated that for Swiss banks, an increase in available capital through retained earnings or equity issues is less costly than a downward adjustment in portfolio risk. Absence of a developed market for asset-backed securities in Switzerland could be a plausible explanation for the relative rigidity of Swiss banks' portfolios in comparison to what was observed in studies on US banks.

Recently, Fiordelisi et al. (2011) has used Granger-causality technique to assess the relationship between capital, efficiency and risk for a sample of European commercial banks over the period 1995-2007. The results indicate that inefficient banks typically have higher risk levels while higher capital levels increase bank efficiency. Overall, there is no empirical research investigating the relationship between risk, efficiency and capital in Chinese banking industry. Moreover, Tan and Floros (2013) examined the relationship between bank efficiency, risk and capital for a sample of Chinese commercial banks employing three-stage least square method in a panel data framework. They found that there is a positive and significant relationship between risk and efficiency in Chinese banking industry, while the relationship between risk and capitalization is negative and significant. They concluded that bigger banks (in terms of total assets) have higher technical and pure technical efficiencies, while Chinese banks with higher liquidity have lower technical and pure technical efficiencies. Furthermore, in a higher concentrated banking market, technical and pure technical efficiencies of Chinese banks are lower. As for the relationship between risk, capital and bank productivity, the results indicate that banks with higher liquidity are more capitalized. 
Lee and Hsieh (2013) applied the Generalized Method of Moments technique for dynamic panels using bank-level data for 42 Asian countries over the period 1994 to 2008 to investigate the impacts of bank capital on profitability and risk. They found that commercial banks reveal the highest reverse capital effect on risk. In addition, banks in low-income countries have a higher capital effect on profitability; banks in lower-middle income countries have the highest reverse capital effect on risk, while banks in high-income countries have the lowest values and banks in Middle Eastern countries own the highest and positive capital effect on profitability. Far East \& Central Asian banks have the largest reverse capital effect on risk, while the lowest value is found in Middle Eastern countries' banks. They explained their results by the effect of influence factors. Therefore, Teixeira et al. (2014) investigated whether regulatory capital requirements play an important role in determining banks' equity capital, using panel data of a sample of 560 banks during 2004-2010. Their results indicate that regulatory capital requirements are not first order determinants of banks' capital structure. They found differences in the effect of most factors on banks' share of equity according to the type of bank and to the region of the bank.

Guidara et al. (2013), using quarterly financial statements and stock market data from 1982 to 2010 for the six largest Canadian chartered banks, found that Canadian banks are well capitalized, which explained why they avoided the recent financial crisis so well. They note that bank capital buffers exhibit a positive co-movement with business cycles. This result holds even with changes in regulatory regimes. They also found no strong evidence that variations of banks' capital buffer impacts banks' exposure to risks and return on equity. By and large, there is no strong relationship between capital buffers and risk. Hence, the motive to hold an excess capital buffer may be driven by market discipline. They present two main policy implications on the basis of the Canadian experience. First, rigorous and strict implementation of both risk-based and non-risk-based capital requirements can help mitigate the well-documented procyclicity associated with current Basel risk-based capital charges. Second, increases in capital requirements should occur during periods of strong economic growth because it is during these periods that banks can accumulate more capital. Conversely, during recessionary times, a reduction in capital requirements would be desirable since it may provide more flexibility for banks to survive downturns.

More recently, Ben Bouheni et al. (2014) studied the effects of regulatory and supervisory policies on profitability and risk-taking of European banks over the period 2005 to 2011, using the Generalized Method of Moments (GMM) for dynamic panels. Their aim was to further capture heterogeneous supervision effects before and after the subprime crisis. They reached three main results. First, strengthening regulations and supervision improves profitability and boosts the stability of European banking systems. Second, their findings revealed a positive correlation between capital adequacy, deposit insurance systems and banks' profitability. Third, they note that stepping up supervisors' powers reduces risk-taking and promotes banking stability.

\section{THE EMPIRICAL STUDY}

\section{Presentation Of Models And The Sample}

Our aim is to investigate the reactions of Tunisian commercial banks to regulatory pressure in terms of capital and risk decisions. To this end, we estimate the following system equation:

Capital equation:

$\operatorname{Cap}_{i t}=\alpha_{i}+\beta_{1} \mathrm{Liq}_{\mathrm{it}}+\beta_{2} \mathrm{Size}_{\mathrm{it}}+\beta_{3} \mathrm{ROA}_{\mathrm{it}}+\beta_{4} \mathrm{ROE}_{\mathrm{it}}+\beta_{5} \operatorname{Pres}_{\mathrm{it}}+\beta_{6} \mathrm{Risk}_{\mathrm{it}}+\varepsilon_{1 i t}$

Risk equation:

$R i s k_{i t}=\lambda_{i}+\delta_{1} \mathrm{Liq}_{\mathrm{it}}+\delta_{2} \mathrm{Size}_{\mathrm{it}}+\delta_{3} R O A_{i t}+\delta_{4} \mathrm{ROE}_{\mathrm{it}}+\delta_{5} \operatorname{Pres}_{\mathrm{it}}+\delta_{6} \operatorname{Cap}_{i t}+\varepsilon_{2 i t}$ 
- Where, subscripts i denotes individual 11 banks (Amen Bank, Arab Tunisian Bank, Banque de l'Habitat, Banque Internationale Arabe de Tunisie, Banque Nationale Agricole, Attijari Bank, Banque de Tunisie, Société Tunisienne de Banque, Banque de Tunisie et des Emirats, Union Internationale de Banques and Union Bancaire pour le Commerce et l'Industrie), $\mathrm{t}$ time period $(\mathrm{t}=2000,2013) . \quad \beta$ and $\delta$ are the parameters to be estimated. $\varepsilon$ is the error term.

- $\quad$ Bank capital (Cap): measured by equity-to-total assets.

- $\quad$ Risk: Several different measures of bank risk-taking have been used in empirical studies. In this study, like Aggarwal and Jacques (2001), we measure risk using the ratio of weighted-assets to total assets.

- $\quad$ Bank size (Size): Natural Logarithm of total assets as at the end of each fiscal year.

- $\quad$ Liquidity (Liq): Net Loans over Total assets

- $\quad$ Profitability: Because there is no single, unique measure of bank profitability, we employ two alternatives. These are ROA (return on assets) and ROE (return on equity).

- $\quad$ Regulatory pressure (Pres): Dummy variable, which takes the value of unity if the bank's capital ratio is within one standard deviation of the minimum capital requirement, and zero otherwise (Rime 2001).

The sample examined in this paper consists of the largest banks in Tunisia over the period 2000-2013. The data is taken from the Tunis Stock Exchange and from Annual Reports.

\section{Two SLS And 3SLS Of Baltagi (2005)}

Ordinary least squares (OLS) are not appropriate for estimating simultaneous equation systems since equations' error terms generally correlate with the endogenous variables included in each equation as explanatory variables. The endogeneity of capital and risk adjustments is recognized by the two-stage least squares (2SLS) methodology which provides consistent parameter estimates (Abreu and Gulamhussen).

First, we test endogneity of Bank Capital and Risk using the Durbin-Wu-Hausman test. This test confirms the endogeneity of the two variables (P-value are less 5\%). To resolve endogeneity bias, we use the first risk lag in the first equation and bank capital in the second equation.

Table 1: Endogeneity Test: Durbin-Wu-Hausman Test

\begin{tabular}{ll}
\hline Bank Capital & Chi-sq $=13.22(\mathrm{P}$-value $=0.000)$ \\
Risk & Chi-sq $=16.47(\mathrm{P}$-value $=0.000)$ \\
\hline
\end{tabular}

Table 2: Two-Stage Least Square: 2SLS Of Baltagi

\begin{tabular}{|c|c|c|c|c|}
\hline Size & $\begin{array}{c}\text { 2SLS With Fixed } \\
\text { Effects Bank Capital } \\
-0.165 \\
(1.11) \\
\end{array}$ & $\begin{array}{c}\text { Risk } \\
-0.122 * * * \\
(2.23) \\
\end{array}$ & $\begin{array}{c}\text { 2SLS With Random } \\
\text { Effects Bank Capital } \\
-0.192 \\
(1.47) \\
\end{array}$ & $\begin{array}{c}\text { Risk } \\
-0.144 * * * \\
(3.14)\end{array}$ \\
\hline Liq & $\begin{array}{l}0.345 \\
(0.88) \\
\end{array}$ & $\begin{array}{l}0.675 \\
(1.54) \\
\end{array}$ & $\begin{array}{r}0.682 \\
(1.40) \\
\end{array}$ & $\begin{array}{l}0.567 \\
(0.66) \\
\end{array}$ \\
\hline ROE & $\begin{array}{c}-0.675^{* * *} \\
(2.73)\end{array}$ & $\begin{array}{l}-0.875 \\
(0.66)\end{array}$ & $\begin{array}{c}-0.841 * * * \\
(2.91)\end{array}$ & $\begin{array}{c}-0.622 * \\
(1.60)\end{array}$ \\
\hline ROA & $\begin{array}{c}0.212 * * \\
(2.51) \\
\end{array}$ & $\begin{array}{l}0.011 \\
(0.25)\end{array}$ & $\begin{array}{c}0.378 * * * \\
(2.90)\end{array}$ & $\begin{array}{l}0.336 \\
(1.13)\end{array}$ \\
\hline Pres & $\begin{array}{c}-0.078 \\
(0.65) \\
\end{array}$ & $\begin{array}{l}-1.056 \\
(0.19) \\
\end{array}$ & $\begin{array}{l}-0.006 \\
(1.40) \\
\end{array}$ & $\begin{array}{l}-0.475 \\
(1.39) \\
\end{array}$ \\
\hline L.Risk & $\begin{array}{c}-0.123 * * * \\
(3.38)\end{array}$ & & $\begin{array}{c}-0.365^{* *} \\
(2.12) \\
\end{array}$ & \\
\hline L.Bank capital & & $\begin{array}{c}0.234 * * \\
(2.59)\end{array}$ & & $\begin{array}{c}0.098 * * \\
(2.31)\end{array}$ \\
\hline $\begin{array}{l}\text { R square } \\
\mathrm{N}\end{array}$ & $\begin{array}{c}0.278 \\
154\end{array}$ & $\begin{array}{c}0.298 \\
154\end{array}$ & $\begin{array}{c}0.313 \\
154\end{array}$ & $\begin{array}{c}0.345 \\
154\end{array}$ \\
\hline
\end{tabular}

Hausman test

Bank Capital Chi-sq $(6)=3.99(\mathrm{P}$-value $=0.734)$ : 2 SLS with random effects

Risk Chi-sq $(6)=0.58(\mathrm{P}$-value $=0.983)$ : $2 \mathrm{SLS}$ with random effects

$* * *, * *$ and $*$ denote significance at the $1 \%, 5 \%$ and $10 \%$ levels, respectively.

The numbers in parentheses are the absolute values of t-statistics. 
The Hausman test confirms the appropriateness of the random effect with instrumental variables procedure used in this study (the two P-values of Hausman statistics are larger than 5\%). Instrumental variables are statistically insignificant and have negative signs; capitalization negatively correlates with level of lagged risk, which implies that a significant lagged risk level may follow a lower capital level. Moreover, size and liquidity exert negligible and insignificant effects on capital ratio. The two profitability measures have expected signs and are statistically significant. In the second equation -risk level- only size has a significant impact on the dependent variable with a relatively high coefficient $(-0.81341)$.

For robustness checks, like Aggarwal and Jacques (2001), the simultaneous equation model is estimated using the 3SLS procedure which admits endogoneity of both bank capital ratio and risk levels. 3SLS provides consistent estimates of parameters because it is a well-information estimator and produces parameter estimates more asymptotically and more efficient than those of 2SLS.

Table 3: Three-Stage Least Square: 3SLS Of Baltagi

\begin{tabular}{|c|c|c|}
\hline Variables & Within 3SLS & Error Component 3SLS \\
\hline Size & $\begin{array}{c}\text { Bank Capital } \\
-0.023 * * \\
(2.34) \\
\end{array}$ & $\begin{array}{c}\text { Bank Capital } \\
-0.044^{* *} \\
(1.90) \\
\end{array}$ \\
\hline Liq & $\begin{array}{l}0.120 \\
(0.67) \\
\end{array}$ & $\begin{array}{r}0.126 \\
(1.40) \\
\end{array}$ \\
\hline ROE & $\begin{array}{c}-0.343^{* * *} \\
(2.60)\end{array}$ & $\begin{array}{c}-0.213^{* * *} \\
(2.58)\end{array}$ \\
\hline ROA & $\begin{array}{c}0.065^{* * *} \\
(3.34)\end{array}$ & $\begin{array}{c}0.054 * * * \\
(3.12)\end{array}$ \\
\hline Pres & $\begin{array}{c}-0.006^{*} \\
(1.64) \\
\end{array}$ & $\begin{array}{c}-0.004 * \\
(1.71) \\
\end{array}$ \\
\hline Risk & $\begin{array}{c}-0.085^{* *} \\
(2.41) \\
\end{array}$ & $\begin{array}{c}-0.066^{* *} \\
(1.87) \\
\end{array}$ \\
\hline & Risk & Risk \\
\hline Size & $\begin{array}{c}-0.033^{* * *} \\
(3.35) \\
\end{array}$ & $\begin{array}{c}-0.023 * * * \\
(3.12)\end{array}$ \\
\hline Liq & $\begin{array}{l}0.008 \\
(0.98) \\
\end{array}$ & $\begin{array}{l}0.006 \\
(0.66) \\
\end{array}$ \\
\hline ROE & $\begin{array}{c}0.078 * * * \\
(0.98)\end{array}$ & $\begin{array}{c}-0.091 * * * \\
(3.12)\end{array}$ \\
\hline ROA & $\begin{array}{l}0.002 \\
(0.38) \\
\end{array}$ & $\begin{array}{c}0.043 * * * \\
(3.09)\end{array}$ \\
\hline Pres & $\begin{array}{r}-0.014 \\
(0.58) \\
\end{array}$ & $\begin{array}{r}-0.011 \\
(0.65) \\
\end{array}$ \\
\hline Bank Capital & $\begin{array}{c}-0.098^{* * *} \\
(2.66) \\
\end{array}$ & $\begin{array}{c}-0.078^{* * * *} \\
(2.67)\end{array}$ \\
\hline System weighted R-square & 0.286 & 0.217 \\
\hline
\end{tabular}

$* * *, * *$ and $*$ denote significance at the $1 \%, 5 \%$ and $10 \%$ levels, respectively. The numbers in parentheses are the absolute values of t-statistics.

The Hausman test also confirms the appropriateness of the random effect (EC3SLS) estimation procedure (P-value of Hausman statistics are larger than 5\%). We noticed that the interaction between capitalization and risk level is negative and not significant, which means that capital requirement increases capital level but pushes banks to reduce their risk appetite. Hence, an increase in capital level is followed by a decrease in banking risk-taking. This result is confirmed by the findings of Mongid and Haron (2012) for the ASEAN countries, and Aguidara Tchana (2013) in their study of Canadian banks, allowing us to conclude that the preconditions necessary for the proper functioning of capital adequacy are absent as indicated by Daoud (2003) and unlike the studies of Awdeh (2011), Aggarwal and Jacques (2001) and Rime (2001).

Return on assets (ROA) is positively associated with change in capital ratio at the $1 \%$ significance. Altunbas (2007) showed that ROA may lead to an improvement in capital ratios and to banks relying on asset returns to improve their capital instead of investing in other activities, particularly securitization, contrary to Zhang 
et al. (2008) who found a negative relationship between bank size and its capitalization. This finding was explained by the use of banks' subordinated debt, pump priming, and entry in capital markets rather than self-financing. The results show also that this variable is negative and statistically significant in the risk equation. This finding is similar to that of Awdeh (2011). The regulatory pressure variable shows the weak institutional and regulatory role of Tunisian banks. Thus, it has no significant effect on the two equations. We found a similar result about the impact of the regulatory variable on capital ratio CAR, like Awdeh (2011). Unlike Zhang et al. (2008) who found that the regulatory constraint is statistically significant and positively correlates with change in capital. In our study, it is found to have a negative and statistically insignificant sign. The same conclusion was reached by Aggarwal and Jacques (2001).

Moreover, size is highly significant in the risk equation, indicating that the larger the banks are, the more they manage their risk. Similarly, Altunbas (2007) found that, in the largest banks, risk level decreases and so does capital ratio. The author concludes that large banks have more experience in managing risk levels through diversification. Bank size in both equations has a positive and statistically significant impact. Thus, large banks have more opportunities to invest, consistent with the diversification hypothesis (Zhang et al. 2008). The negative relationship between size and bank capitalization was mainly explained by the direct and easy access to major banks in capital markets, the larger bank size is, the lower risk level is (Aggarwal and Jacques, 2001). Awdeh (2011) explains that by the TBTF phenomenon. The liquidity variable is not significant in our two equations. This variable has a negative and statistically significant coefficient for risk, which means that a larger volume of loans is associated with greater capitalization, like the case of deposit banks and cooperative banks.

\section{CONCLUSION}

To investigate the reactions of Tunisian commercial banks to regulatory pressure in terms of capital and risk decisions, we studied a sample containing the largest banks in Tunisia over the period 2000-2013 using the simultaneous equation model. We found that interaction between capitalization and risk level is negative and not significant, indicating that an increase in capital is followed by a decrease in banking risk-taking. Moreover, return on assets (ROA) is positively associated with change in capital ratio, showing a weak institutional and regulatory level of Tunisian banks. Then, size is highly significant in the risk equation, which means that more banks are large, more they manage their risk. Thus, large banks have more experience in managing risk levels through diversification. Finally, we found a negative relationship between size and bank capitalization. This latter finding is mainly explained by the direct and easy access to major banks in capital markets, i.e. the largest banks are associated to low risk level

\section{AUTHOR INFORMATION}

Dr. Faten Ben Bouheni is a Pofessor of Finance at ISC Paris Business School and a Researcher at LITEM research laboratory in France. Her research focuses on financial institutions, mainly banks, with special emphasis on regulatory and supervisory issues. Email: fbenbouheni@iscparis.com

Houssem Rachdi, Ph.D., Faculty of Law, Economics and Management of Jendouba, University of Jendouba, Tunisia. EQAF Research laboratory: Faculty of Economic Sciences and Management of Tunis, University of Tunis El Manar, Tunisia. Houssem Rachdi holds Ph.D. as well as a M.Sc. and a B.Sc. degrees in Financial and Banking Economics. He is an Associate Professor at Faculty of Law, Economics and Management of Jendouba, Tunisia. His research interests include issues of financial development, economic growth, corporate and banking performance, bank risk taking, institutions quality, banking and financial crises, prudential and banking supervision, corporate governance and Islamic finance. Email: rachdih@uvic.ca 


\section{REFERENCES}

1. Aggarwal, R., and Jacques, K.T., 2001. The impact of FDICIA and prompt corrective action on bank capital and risk: Estimates using a simultaneous equations model. Journal of Banking and Finance 25, $1139-1160$

2. Agusman, A., Monroe, G.S., Gasbarro, D., Zumwalt, J.K., 2008. Accounting and capital market measures of risk: evidence from Asian banks during 1998-2003. Journal of Banking and Finance 32 (4), 480-488

3. Altunbas, Y.S., Carbo, E., Gardener, P.M., Molyneux, P., 2007. Examining the relationships between capital, risk and efficiency in European banking. European Financial Management 13 (1), 49-70

4. Barth, J., Caprio, G., Levine, R., 2008. Bank regulations are changing: for better or worse? Comparative Economic Studies 50 (4), 537-563

5. Ben Bouheni, F., 2013. L'impact de la régulation et de la supervision sur la rentabilité bancaire. La Revue du Financier, Vol. 35, $\mathrm{N}^{\circ} 203$, p. 52-66

6. Ben Bouheni, F., 2014. Banking regulation and supervision: can it enhance stability of banks in Europe, accepted, Journal of Financial Economic Policy, Vol. 6 - Iss:3

7. Ben Bouheni, F., Ben Ameur, H., Idi Cheffou, H., Jawadi, F. 2014. The Effects of Regulation and Supervision on European Banking Profitability and Risk: A Panel Data Investigation. Journal of Applied Business Research.

8. Berger, A.N.,1995. The relationship between capital and earnings in banking. Journal of Money, Credit and Banking 27 (2), 432-456

9. Brewer Jr., E., Lee, C.F., 1986. How the market Judges bank risk, economic perspectives. Federal Reserve Bank of Chicago, 25-31.

10. Demirgü.-Kunt, A., Huizinga, H., 2000. Financial Structure and Bank Profitability. The World Bank Policy Research Working Paper, No. 2430.

11. Demirgü.-Kunt, A., Kane, E., 2002. Deposit insurance around the world: where does it work? Journal of Economic Perspectives 16 (2), 175-195

12. Festic, M., Kavkler, A., Repina, S., 2011. The macroeconomic sources of systemic risk in the banking sectors of five new EU member states. Journal of Banking and Finance 35 (2), 310-322.

13. Fiordelisi, F., Marques-lbanez, D., Molyneux, P., 2011. Efficiency and risk in European banking. Journal of Banking and Finance 35, 1315-1326.

14. Guidara, A., Lai, V.S., Soumaré, I., Tchana, T.F., 2013. Banks' capital buffer, risk and performance in the Canadian banking system: Impact of business cycles and regulatory changes. Journal of Banking and Finance 37, 3373-3387

15. Hughes, J.P., Mester, L., 1998. Bank capitalization and cost: evidence of scale economies in risk management and signaling. Review of Economics and Statistics 80 (2), 314-325

16. Hughes, J.P., Moon, C., 1995. Measuring Bank Efficiency When Managers Trade Return for Reduced Risk. Department of Economics Rutgers University Working Paper, No. 1995-20

17. Iannotta, G., Nocera, G., Sironi, A., 2007. Ownership structure, risk and performance in the European banking industry. Journal of Banking and Finance 31 (7), 2127-2149

18. Jacques, K., Nigro, P., 1997. Risk-based capital, portfolio risk and bank capital: a simultaneous equations approach. Journal of Economics and Business 49 (6), 533-547

19. Jahankhani, A., Lynge Jr., M.J., 1980. Commercial bank financial policies and their impact on marketdetermined measures of risk. Journal of Bank Research 11 (3), 169-178

20. Kahane, Y., 1977. Capital adequacy and the regulation of financial intermediaries. Journal of Banking and Finance 1 (2), 207-218.

21. Karels, G.V., Prakash, A.J., Roussakis, E., 1989. The relationship between bank capital adequacy and market measures of risk. Journal of Business Finance and Accounting 16 (5), 663-673

22. Keeley, M.C., Furlong, F.T., (1990), "A re-examination of mean-variance analysis of bank capital regulations", Journal of Banking and Finance 14, 69-84.

23. Kim, D., Santomero, A.M., 1988. Risk in banking and capital regulation. Journal of Finance 43 (5), 12191233.

24. Koehn, M., Santomero, A., 1980. Regulation of bank capital and portfolio risk. Journal of Finance 35 (5), $1235-1245$ 
25. Lee, C-C., Hsieh, M-F., 2013. The impact of bank capital on profitability and risk in Asian banking. Journal of international money and finance 32, $251-281$

26. Murphy, K. J., 2013. Regulating Banking Bonuses in the European Union: A Case Study in Unintended Consequences, European Financial Management, Vol. 19(4), S. 631-657

27. Pettway, R.H., 1976. Market tests of capital adequacy of large commercial banks. Journal of Finance 31 (3), 865-875

28. Rime, B., 2001. Capital requirements and bank behaviour: Empirical evidence for Switzerland. Journal of Banking and Finance 25, 789-805

29. Shrieves, R.E., Dahl, D., 1992. The relationship between risk and capital in commercial banks. Journal of Banking and Finance 16 (2), 439-457

30. Tan, Y., Floros, C., 2013. Risk, capital and efficiency in Chinese banking. Journal of International Financial Markets, Institutions \& Money 26, 378-393

31. Teixeira, J.C.A., Silva, F.J.F., Fernandes, A.V., Alves, A.C.G., 2014. Banks' capital, regulation and the financial crisis. North American Journal of Economics and Finance, http://dx.doi.org/10.1016/j.najef.2014.01.002

32. Zhang, Z-Y., Wu, J., Liu Q.F., 2008. Impacts of capital adequacy regulation on risk taking behaviors of banking, System engineering-Theory and Practice 28 (8), 183 - 189 